\title{
BENTUK KETIDAKADILAN GENDER DALAM NASKAH DRAMA MANGIR KARYA PRAMOEDYA ANANTA TOER
}

\author{
Aryani $^{1}$, Rerin Maullinda ${ }^{2}$ \\ ${ }^{12}$ Program Studi Sastra Indonesia, Universitas Pamulang \\ 1dosen01161@unpam.ac.id \\ 2dosen00445@unpam.ac.id
}

\begin{abstract}
Abstrak
Tulisan ini membahas ketidakadilan gender dalam naskah drama Mangir karya Pramoedya Ananta Toer yang menceritakan tentang Wanabaya atau pemimpin kerajaan Mangir yang memimpin anak buahnya untuk berperang dengan Mataram. Tulisan ini bertujuan untuk mendeskripsikan pandangan feminisme terhadap ketidakadilan gender dalam naskah drama Mangir. Analisis data dilakukan dengan metode deskriptif dengan pendekatan feminism. Data dari penelitian ini berupa data verbal, paparan bahasa pernyataan tokoh berupa dialog, monolog, dan narasi yang ada dalam naskah drama Mangir karya Prmoedya Ananta Toer. Deskripsi pembahasan difokuskan pada naskah drama yang memunculkan adanya bentuk ketidakadilan gender dalam paham feminisme. Hasil pembahasan menunjukkan bahwa Berdasarkan data dan analisis data di atas, ditemukan beberapa bentuk ketidakadilan gender dalam naskah drama Mangir karya Pramoedya Ananta Toer, bentuk ketidakadilan gender tersebut berupa: Stereotipe (stereotipe terhadap rakyat jelata dan perempuan), Beban kerja (beban kerja terhadap rakyat jelata dan perempuan), kekerasa (fisik dan psikologi), dan subordinasi(subordinasi terhadap perempuan dan prajurit)
\end{abstract}

Kata Kunci: Bentuk Ketidakadilan, Gender, Naskah Drama

\section{Pendahuluan}

Karya sastra merupakan sebuah mimesis yang bercampur proses kreatifitas. Oleh karena itu, karya sastra kerap kali menampilkan sesuatu yang ada di dalam kehidupan bermasyarakat, salah satunya adalah permasalahan tentang gender. Ketidakadilan gender merupakan permasalahan yang belum terselesaikan. Adanya keegoisan dalam setiap diri manusia menyebabkan munculnya motifasi untuk berkembang maju dan mengalahkan para kompetitor. Untuk mencapai keinginan untuk lebih maju dari individu bahkan kelompok lainnya, maka manusia 
cenderung menunjukkan apa yang menjadi keunggulan yang mereka miliki. Keunggulan tersebut dinilai berdasarkan subjektifitas yang didukung oleh lingkungan bahkan kebudayaan. Sehingga, dari penilaian tersebut muncul berbagai stigma yang meluas dan dianggap sebagai kodrat Tuhan. Permasalahan tersebut akan memunculkan manifestasi ketidakadilan gender. Bahayanya, ketidakadilan gender tersebut akan menjadi kebudayaan bahkan kebiasaan.

Teori feminisme muncul guna menyadarkan masyarakat terhadap kebiasaan buruk di atas. Menurut Maggie Hum dalam Nurgiyantoro (2013: 108) feminisme adalah gerakan persamaan hak asasi bagi perempuan dengan ideologi transformasi sosial yang bertujuan menciptakan dunia bagi perempuan. Meskipun pokok utama pembelaan feminisme condong kepada perempuan, gerakan ini juga memperhatikan ketidakadilan gender yang dialami semua orang. Menurut Fakih (2013: 12) ketidakadilan gender merupakan sistem dan struktur di mana laki-laki dan perempuan menjadi korbannya.

Karena permasalahan gender sangat beragam, teori yang lebih ampuh untuk menganalisanya adalah feminisme multikultural. Salah satu bagian dari feminisme multikultural adalah feminisme dunia ketiga. Menurut Gandhi dalam Wiyatmi (2012) feminisme dunia ketiga merupakan teori yang berusaha memukul balik hierarki gender, budaya, dan ras yang telah ada dan bersumber dari sistem patriarkat atau kolonialisme di masyarakat itu sendiri.

Ketidakadilan gender sudah sangat melekat di kehidupan manusia, maka banyak juga karya sastra yang mempresentasikan permasalahan ketidakadilan gender tersebut. Karya sastra mampu untuk menyadarkan seorang pembaca. Karena itu, karya sastra dianggap sebagai objek yang tepat untuk para pendukung gerakan feminisme dalam menyebarkan gagasannya. Gambaran tentang ketidakadilan gender terlihat sangat beragam. Oleh karena itu, menarik untuk menganalisis bentuk ketidakadilan gender. Seperti yang telah disinggung sebelumnya bahwa karya sastra merupakan mimesis yang bisa mempengaruhi pemikiran pembaca. Maka, menarik untuk menjadikan karya sastra sebagai objek penelitian, dengan demikian penelitian yang akan dilakukan adalah menganalisis 
manifestasi ketidakadilan gender pada karya sastra. Salah satu karya sastra yang kemungkinan besar terdapat bentuk ketidakadilan gendernya adalah karya sastra yang bernuansa kerajaan, karena di dalam kerajaan terdapat sistem patriarki yang dominan. Salah satu karya sastra yang bernuansa kerajaan adalah naskah drama Mangir karya Pramoedya Ananta Toer. Oleh karena itu, menarik untuk menganalisis bentuk ketidakadilan gender dalam naskah drama Mangir karya Pramoedya Ananta Toer.

\section{Metode Penelitian}

Penelitian ini menggunakan penelitian kualitatif dengan pendekatan feminis, karena data yang dianalisis dalam penelitian ini berupa kata-kata atau kaliat yang terdapat dalam naskah drama Mangir karya Pramoedya Ananta Toer. Metode yang digunakan pada penelitian ini adalah metode kualitatif deskriptif dengan teknik analisi isi, menganalisi isi teks naskah drama yang berupa kata-kata atau kalimat dengan menggunakan pendekatan feminism. Data-data yang telah diperoleh kemudian dideskripsikan kembali. Data pada penelitia ini adalah kata atau kalimat yang menggambarkan bentuk ketidakadilan gender pada Naskah drama Mangir adalah naskah drama karya Pramoedya Ananta Toer yang diterbitkan oleh KPG sejak tahun 2000 - cetakan ke-9 di tahun 2015. Naskah drama ini berbentuk buku dengan 114 halaman, dengan ukuran 13,5 x $20 \mathrm{~cm}$. Secara garis besar, naskah drama ini menceritakan tentang Wanabaya atau pemimpin kerajaan Mangir yang memimpin anak buahnya untuk berperang dengan Mataram.

\section{Pembahasan}

\section{Bentuk Ketidakadilan Gender dalam Naskah Drama Mangir Karya Pramoedya Ananta Toer}

Naskah drama Mangir adalah naskah drama karya Pramoedya Ananta Toer yang diterbitkan oleh KPG sejak tahun 2000 - cetakan ke-9 di tahun 2015. Naskah drama ini berbentuk buku dengan 114 halaman, dengan ukuran 13,5 x 20 
$\mathrm{cm}$. Secara garis besar, naskah drama ini menceritakan tentang Wanabaya atau pemimpin kerajaan Mangir yang memimpin anak buahnya untuk berperang dengan Mataram. Raja Mataram yang hampir kalah merasa geram dengan Mangir, oleh karena itu ia mengutus putrinya untuk memikat hati Raja Mangir lalu menjadi mata-mata di kerajaan tersebut. Suatu hari, Wanabaya menikah dengan seorang penari keliling yang ternyata Putri Raja Mataram (Putri Pembayun). Singkat cerita, Wanabaya diundang ke istana, namun di sanalah Wanabaya dibunuh oleh Raja Mataram.

Seperti yang telah disinggung di atas bahwa bentuk ketidakadilan gender sangat beragam, maka kemungkinan besar data yang ditemukan juga beragam, akan tetapi data yang akan dianalisis adalah data yang menunjukkan bentuk ketidakadilan gender. Berikut data yang berupa kutipan dalam naskah drama Mangir karya Pramoedya Ananta Toer:

\section{Data 01}

BARU KLINTING

: Semakin banyak tombak kau tempa, semakin banyak kau bicara. Panggil sini orang baru pembikin tangkai tombak itu.

SURIWANG : (berpaling dan melambai). Sini kau, orang baru!

KIMONG : (masuk ke panggung, membungkuk-bungkuk, kemudian mengangkat sembah): Kimong, inilah sahaya. (Toer, 2015: 9)

Berdasarkan data 01 di atas, sistem kelas antara orang kerajaan dan bukan orang kerajaan begitu jelas terlihat, yang mana Kimong yang bukan orang kerajaan sampai mengangkat sembah kepada Baru Klinting dan Suriwang. Hal ini menunjukkan dominasi yang dilakukan oleh orang kerajaan, dengan adanya dominasi tersebut maka akan menimbulkan bentuk kekerasan gender berupa stereotipe bahwa rakyat jelata memiliki derajat yang rendah, maka ia berhak diperintah dan tidak berhak dihormati. Apabila demikian, maka bentuk ketidakadilan gender yang muncul selanjutnya adalah beban kerja yang berlebih. 


\section{Data 02}

DEMANG PAJANGAN : Apa guna jadi pria kalau bukan untuk mendapatkan wanita?

DEMANG PANDAK : : Tidak bisa. Untuk sekarang ini, tidak bisa.(Toer, 2015: 17)

Berdasarkan data 02 di atas, menunjukkan bahwa wanita dianggap sebagai objek yang harus didapatkan oleh pria, terbukti dari kalimat "Apa guna jadi pria kalau bukan untuk mendapatkan wanita". Di sini menunjukkan bahwa pria terkesan hebat dan berguna apabila sudah mendapatkan wanita. Dengan demikian, posisi wanita dianggap seperti barang yang harus didapatkan. Anggapan tersebut merupakan bentuk dari ketidakadilan gender karena dapat membuat wanita merasa rendah, hal ini termasuk dalam bentuk dari kekerasan secara psikologi. Akibat dari kekerasan psikologi itu, maka wanita akan menganggap dirinya tidak patut berkontribusi dalam suatu hal, ini juga yang akan menimbulkan subordinasi atau anggapan tidak terlalu penting terhadap objek yang dalam konteks ini adalah posisi wanita.

\section{Data 03}

DEMANG PATALAN : Aku mengerti, kau tak setuju itu. Tapi Ki Wanabaya bermain berahi, dalam keadaan belum selesai.

\section{BARU KLINTING}

: Untuk bersuka sekedarnya tak ada celanya. Dia berhak sebagai panglima, telah selamatkan kalian semua, kademangan dan semua rakyatnya.(Toer, 2015: 22)

Berdasarkan data 03 di atas, menunjukkan bahwa sistem kelas sangat mempengaruhi hak seseorang, terbukti dari ucapan Baru Klinting yang menunjukkan bahwa Wanabaya sebagai panglima berhak bersuka dengan wanita. Hal ini dapat menimbulkan opsi yang berarti bahwa selain Wanabaya tidak boleh 
bersuka. Artinya, hanya seorang pemimpinlah yang berhak bersuka, sementara anak buahnya tidak berhak untuk bersuka-ria. Dengan demikian hal ini menunjukkan bahwa kelas sosial dalam struktur kerajaan melahirkan bentuk ketidakadilan gender yang mana seorang prajurit tersubordinasi dalam bentuk dianggap tidak penting dalam hal bersuka-ria.

\section{Data 04}

WANABAYA

PUTRI PAMBAYUN
: Inilah Ki Ageng Mangir Muda Wanabaya, datang menggandeng tandak tanpa tandingan. (Menatap mereka seorang demi seorang). Tak ada yang menyambut Ki Wanabaya? Baik Adisaroh yang jaya, berilah hormat pada para tetua Perdikan.

:(tetap dalam gandingan Wanabaya). Inilah Adisaroh Waranggana bayaran, mengembara dari desa ke desa mencari penghidupan. (memberi hormat dengan gerak badan). Di belakang menyusul rombongan wiyaga.(Toer, 2015: 25)

Berdasarkan data 04 di atas, terlihat bahwa Adisaroh yang berperan sebagai orang biasa atau rakyat jelata diharuskan untuk menghormati orang-orang kerajaan. Sikap seperti itu akan melahirkan subordinasi yang mana rakyat jelata merasa tidak pantas berkontribusi dalam suatu hal yang menyangkut kerajaan. Hal tersebut akan melahirkan anggapan bahwa suara atau masukan dari rakyat jelata tidak perlu di dengar. Dengan demikian, bentuk pengharusan untuk menghormat pada orang-orang kerajaan akan menimbulkan bentuk ketidakadilan gender berupa subordinasi.

\section{Data 05}

PUTRI PAMBAYUN : Dalam gandingan tangan Ki Wanabaya Muda, bahkan di bawah bayang-bayangnya, semut pun tiada kan gentar. 
WANABAYA

: Benar sekali, semut pun tiada kan kecut. (mengangkat gandingan tinggi-tinggi). Inilah Adisaroh, perawan waranggana kubawa kemari akan kuambil untuk diriku sendiri.(Toer, 2015: 28)

Berdasarkan data 05 di atas, sangat jelas terlihat bahwa Adisaroh dianggap seperti barang, terbukti dari kalimat "Inilah Adisaroh, perawan waranggana kubawa kemari akan kuambil untuk diriku sendiri”. Hal ini menunjukkan dominasi yang dilakukan oleh orang kerajaan khususnya Wanabaya yang notabene-nya sebagai raja. Perilaku yang ditunjukkan oleh Wanabaya adalah bentuk dari ketidakadilan gender yangmana mengganggap wanita seperti barang yang bisa ia bawa dan ia miliki. Tindakan ini merupakan salah satu bentuk dari stereotipe terhadap wanita karena menganggap wanita sebagai barang.

\section{Data 06}

DEMANG PANDAK

TUMENGGUNG MANDARAKA : Anakku bukan tandak sembarang waranggana, dididik baik tahu adat, terlatih tahu sopan setiap waktu, setiap saat.(Toer, 2015: 29)

Berdasarkan data 06 di atas, menunjukkan bahwa ketidakadilan gender dialami oleh Adisaroh, ia dituduh sebagai wanita milik semua pria. Hal ini menunjukkan bentuk ketidakadilan gender berupa stereotipe atau pelabelan negatif. Stereotipe yang dituduhkan kepada Adidaroh adalah stereotipe yangmana perempuan penari adalah milik semua pria. Hal sangat tidak adil karena belum tentu semua penari keliling bersifat demikian.

\section{Data 07}

BARU KLINTING

: Seperti Mataram miskin putri rupawan. Bedah dulu kratonnya dan kau boleh ponding semua perawannya.(Toer, 2015: 31) 
Berdasarkan data 07 di atas, menunjukkan perendahan terhadap kaum perempuan. Hal ini tercermin dari perkiraan apabila Wanabaya dapat menaklukkan Mataram, maka ia boleh memiliki semua perempuan Mataram. Hal ini merupakan bentuk kekerasan fisik terhadap perempuan yang mana perempuan diharuskan berserah diri, termasuk dimiliki oleh seseorang yang menang perang.

\section{Data 08}

DEMANG PATALAN : : (menghampiri Wanabaya, menyerang). Belum lagi kau injakkan kaki di kraton Mataram - putriputrinya dibesarkan hanya untuk kepuasan pria, halus tak pernah kerja, tak kena sinar surya.(Toer, 2015: 31)

Berdasarkan data 08 di atas, sangat jelas terlihat bahwa derajat perempuan begitu direndahkan, terbukti dari kata-kata "putri-putrinya dibesarkan hanya untuk kepuasan pria". Hal ini menunjukkan bahwa perempuan hanya bertugas untuk melayani pria, dengan demikian sangat jelas terlihat bahwa stereotipe yang dikembangkan adalah derajat perempuan lebih rendah dari laki-laki. Hal ini akan berimplikasi dengan hal lainnya, seperti subordinasi, yangmana perempuan dianggap tidak penting karena hanya sebagai pelayan. Selain subordinasi, ketidakadilan gender selanjutnya adalah kekerasan yangmana perempuan layak diberlakukan dengan kasar karena dianggap milik laki-laki. Bentuk ketidakadilan gender selanjutnya adalah beban kerja berlebih karena perempuan dianggap sebagi pelayan.

\section{Simpulan}

Berdasarkan data dan analisis data di atas, ditemukan beberapa manifestasi ketidakadilan gender dalam naskah drama Mangir karya Pramoedya Ananta Toer,

1) Stereotipe Terhadap Rakyat Jelata dan Wanita, rakyat jelata memiliki derajat yang lebih rendah, dengan demikian mereka boleh diperintah dan tidak berhak dihormati sedangkan wanita seperti barang milik pria, dianggap sebagai pelayan yang hanya bertugas untuk melayani pria. 2) Beban Kerja Berlebih 
Terhadap Rakyat Jelata dan Wanita, beban kerja berlebih ini terlahir karena adanya stereotipe bahwa rakyat jelata berhak diperintah dan wanita merupakan pelayan . 3) Kekerasan Fisik dan Psikologi,ekerasan ini berupa kekerasan fisik dan psikologi yang membuat wanita merasa rendah dan tidak berharga yang mengharuskan wanita berserah diri kepada pria. 4) Subordinasi Terhadap Perempuan dan Prajurit, perempuan dianggap memiliki derajat yang lebih rendah, oleh karena itu ia tidak berhak berkontribusi terhadap sesuatu hal dan prajurit dianggap memiliki derajat yang lebih rendah, oleh karena itu ia tidak berhak bersuka-ria.

Berdasarkan simpulan di atas, terlihat jelas bahwa semua korban ketidakadilan gender adalah wanita dan seseorang yang dianggap memiliki derajat lebih rendah. Apabila dikaitan dengan kehidupan masyarakat Indonesia, nampaknya naskah drama ini merupakan mimesis yang baik. Hal ini terbukti dari adanya bentuk ketidakadilan gender terhadap wanita dan seseorang yang dianggap memiliki derajat yang lebih rendah. Pada kehidupan nyata hal yang demikian kerap terjadi, karya sastra yang merupakan mimesis dari kehidupan nyata nampaknya menggambarkan pula ketidakadilan gender tersebut. Salah satunya ada di dalam naskah drama Mangir karya Pramoedya Ananta Toer.

\section{Daftar Pustaka}

Fakih, Mansour. 2013. Analisis Gender dan Transformasi Sosial. Yogyakarta: Pustaka Pelajar.

Nurgiyantoro, Burhan. 2013. Teori Pengkajian Fiksi. Yogyakarta: Gadjah Mada University Press.

Toer, Pramoedya Ananta. 2015. Mangir. Jakarta: KPG (Kepustakaan Populer Gramedia).

Wiyatmi. 2012. Kritik Sastra Feminis: Teori dan Aplikasinya dalam Karya Sastra Indonesia. Yogyakarta: Penerbit Ombak. 